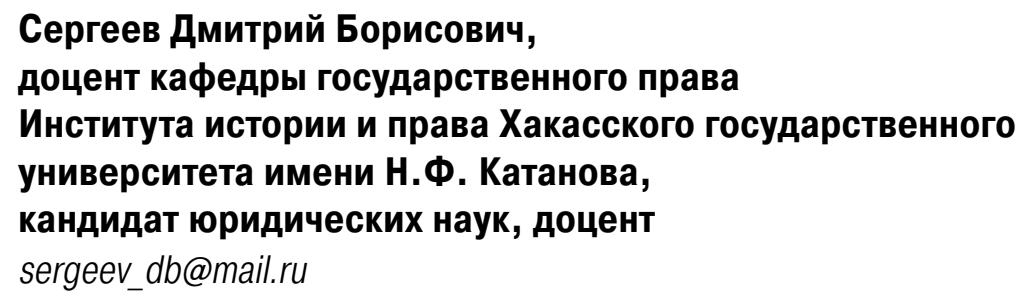

С применением нормативного метода, а также методов сравнения и синтеза изучены и проанализированы идеи конституционализма, положения Конституции Российской Федерации, актов Конституционного Суда Российской Федерации, российского законодательства и содержание трудов ученых-конституционалистов, в которых исследован правовой институт отзыва депутатов законодательных (представительных) государственных и муниципальных органов и избранных должностных лиц органов государственной власти и органов местного самоуправления.

В статье раскрыто наличие конкуренции между некоторыми формами народовластия на отдельных уровнях публичной власти, что негативно влияет на реализацию идей, заложенных в Конституции Российской Федерации, в связи с чем проанализировано соотношение отзыва депутатов законодательных (представительных) государственных и муниципальных органов и избранных должностных лиц органов государственной власти и органов местного самоуправления и выборов как непосредственных форм демократии.

Результаты исследования показывают, что Конституционный Суд Российской Федерации, оценивая конституционность механизмов применения принципов суверенитета народа и привлечения к конституционной ответственности, не нашел сбалансированного разрешения возникших противоречий при реализации норм Конституции Российской Федерации, регулирующих общественные отношения, связанные с институтами отзыва депутатов и избранных должностных лиц, со свободным и императивным депутатскими мандатами.

Ключевые слова: конституционализм, Конституция Российской Федерации, акты Конституционного Суда Российской Федерации, отзыв, выборы, суверенитет народа, свободный депутатский мандат, императивный депутатский мандат.

\title{
ELECTIONS AND RECALL OF DEPUTIES AND ELECTED OFFICIALS ON THE SCALES OF RUSSIAN CONSTITUTIONAL JUSTICE
}

\author{
Sergeev Dmitriy B. \\ Associate Professor of the Department of State Law of the Institute \\ of History and Law of the Katanov Khakass State University \\ Candidate of Legal Sciences \\ Associate Professor
}

The ideas of constitutionalism, provisions of the Constitution of the Russian Federation, acts of the Constitutional Court of the Russian Federation, the Russian legislation and the content of works of scientists-constitutionalists in which legal Institute of the response of deputies of legislative (representative) state and municipal bodies and elected officials of public authorities and local governments is investigated were studied and analyzed using the normative method and methods of comparison and synthesis.

The article reveals the presence of competition between some forms of democracy at certain levels of public power, which negatively affects the implementation of the ideas laid down in the Constitution of the Russian Federation, in connection with which the ratio of the recall of deputies of legislative (representative) state and

\footnotetext{
Статья написана при поддержке СПС «КонсультантПлюс».
} 
municipal bodies and elected officials of public authorities and local authorities and elections as direct forms of democracy is analyzed.

The results of the study show that the Constitutional Court of the Russian Federation, assessing the constitutionality of the mechanisms of application of the principles of sovereignty of the people and bringing to constitutional responsibility, has not found a balanced resolution of the contradictions in the implementation of the Constitution of the Russian Federation, regulating public relations related to the institutions of recall of deputies and elected officials, the ideas of free and mandatory parliamentary mandates.

Keywords: constitutionalism, the Constitution of the Russian Federation, acts of the Constitutional Court of the Russian Federation, recall, elections, sovereignty of the people, free Deputy mandate, imperative Deputy mandate. 